\title{
Penerapan Blended Learning Dalam Mencapai Tujuan Pembelajaran Sosiologi SMA di Masa Pandemi Covid-19
}

\author{
Benny Muhammad ${ }^{1}$, Junaidi Junaidi ${ }^{2}$ \\ ${ }^{1,2}$ Universitas Negeri Padang \\ Email: bennymuhammad274@gmail.com, junaidi@fis.unp.ac.id
}

\begin{abstract}
Abstrak
Pembelajaran di SMA Negeri 3 Kota Pariaman dilaksanakan secara daring dengan memanfaatkan platform e-learning sejak kondisi pandemi Covid-19, namun e-learning tidak digunakan siswa sehingga pihak sekolah menerapkan pembelajaran Blended Learning. Penelitian ini bertujuan untuk mengetahui penerapan Blended Learning di SMA Negeri 3 Kota Pariaman. Pendekatan yang digunakan adalah pendekatan kualitatif tipe studi kasus. Teknik pengumpulan data berupa observasi, wawancara, dan studi dokumentasi. Pemilihan informan dilakukan dengan purposive sampling dengan jumlah informan sebanyak 15 orang terdiri dari kepala sekolah, guru dan siswa. Teknik analisis data menggunakan model interaktif Miles dan Huberman yang terdiri dari reduksi data, penyajian data, dan penarikan kesimpulan. Penelitian ini dianalisis dengan teori tindakan sosial Max Weber. Hasil penelitian menunjukkan bahwa platform e-learning di SMA Negeri 3 Kota Pariaman tidak digunakan oleh siswa, sehingga Blended Learning menjadi alternatif bagi guru dan siswa untuk mencapai tujuan pembelajaran secara optimal.
\end{abstract}

Kata Kunci: Blended Learning, E-learning, Sosiologi, Tujuan Pembelajaran

\section{Abstract}

Learning at SMA Negeri 3 Kota Pariaman is carried out online by utilizing the e-learning platform since the Covid-19 pandemic conditions, but e-learning is not used by student so the school implements Blended Learning. This study aims to determine the application of Blended Learning in SMA Negeri 3 Kota Pariaman. The approach used is a case study type qualitative approach. Data collection techniques in the form of observation, interviews, and documentation studies. The selection of informants was carried out by purposive sampling with a total of 15 informants consisting of principals, teachers and students. The data analysis technique uses the Miles and Huberman interactive model which consists of data reduction, data presentation, and drawing conclusions. This research was analyzed by Max Weber's theory of social action. The results showed that the e-learning platform at SMA Negeri 3 Kota Pariaman was not used by students, so Blended Learning became an alternative for teachers and students to achieve learning objectives optimally. Keywords: Blended Learning, E-Learning, Learning Objectives, Sociology

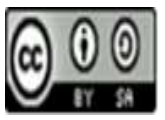




\section{Pendahuluan}

Awal tahun 2020 seluruh dunia khususnya di Indonesia mengalami situasi di luar kendali yang diakibatkan oleh meluasnya wabah Covid-19 diseluruh penjuru dunia. Pandemi Covid-19 berdampak pada berbagai aspek kehidupan termasuk pendidikan saat ini, sehingga mengakibatkan berubahnya proses pembelajaran. Pembelajaran yang sebelumnya berlangsung tatap muka, berubah menjadi pembelajaran jarak jauh dengan penggunaan e-learning. E-learning merupakan suatu proses belajar mengajar antara guru dan siswa tanpa harus melakukan tatap muka satu sama lain (Nasution, 2018). E-Learning diintegrasikan dalam pembelajaran karena menyesuaikan dengan kemajuan teknologi dan informasi dalam dunia pendidikan. Pembelajaran di SMA Negeri 3 Kota Pariaman mengintegrasikan e-learning sebagai proses pelaksanaan pembelajaran, salah satunya pada mata pelajaran sosiologi. Kondisi pandemi saat ini mengharuskan proses pembelajaran beralih dari tatap muka menjadi pembelajaran berbasis daring secara penuh sejak bulan Maret 2020 sampai bulan Desember 2020. Selanjutnya mulai bulan Januari 2021 proses pembelajaran berubah menjadi tatap muka dengan menerapkan blended learning dengan sistem shift. Sistem shift disini merupakan pembelajaran yang tatap mukanya dilakukan secara bergantian pada setiap siswa, misal jumlah siswa pada setiap rombel ada 36 orang, maka kegiatan sekolah tatap muka dalam satu hari hanya setengah dari jumlah siswa tersebut (18 orang). Bagian siswa yang belajar dirumah guru memanfaatkan platform e-learning dalam proses belajar mengajar. Penggunaan e-learning disini bertujuan untuk membantu siswa bagian shift daring saat belajar di rumah, sehingga guru dapat membagikan materi, tugas atau kuis pada siswa yang shift daring tersebut melalui e-learning. Penggunaan e-learning ini juga termasuk salah satu upaya yang dilakukan sekolah untuk mencerdaskan peserta didik dalam hal melek teknologi (Pratama \& Mulyati, 2020).

Proses belajar mengajar yang dilakukan dengan menggunakan e-learning masih banyak terdapat permasalahan, seperti siswa yang tidak bisa menggunakan e-learning dalam pembelajaran walaupun sudah diadakan sosialisasi penggunaan e-learning oleh sekolah. Bentuk sosialisasi yang diberikan oleh sekolah kepada siswa berupa video tutorial dan buku panduan mengenai tata cara penggunaan e-learning. Akan tetapi, pembelajaran jarak jauh tersebut masih saja banyak mengalami kendala dalam pemanfaatan e-learning sebagai media sumber belajar, penyampaian materi, pengambilan absen dan pemberian tugas dalam proses pembelajaran sosiologi masih kurang optimal. Respon siswa terhadap pembelajaran melalui e-learning cukup baik karena dapat membantu siswa itu sendiri dalam proses belajar mengajar secara daring. Namun tidak semua siswa dapat mengikuti pembelajaran daring sosiologi serta tidak mengirim tugas dikarenakan tidak memiliki handphone (hp) dan terkendala koneksi internet yang tidak stabil.

Berdasarkan data yang didapatkan peneliti dapat disimpulkan bahwa pada semester JanuariJuni 2021 terdapat sebesar 62\% siswa yang mengambil absen dan hanya sebesar 30\% siswa yang mengumpulkan tugas melalui e-learning. Hal ini dikarenakan banyaknya siswa yang tempat tinggalnya memiliki sinyal lemah, tidak memiliki handphone (hp) android pribadi, terkendala paket internet, serta tidak mengerti penggunaan e-learning, dan sebagainya. Pembelajaran yang berubah dari pembelajaran tatap muka ke pembelajaran daring secara tidak langsung maka strategi pembelajaran yang dilakukan guru juga akan mengalami perubahan dan penyesuaian. Strategi ini berkaitan dengan materi pelajaran, media, penilaian serta waktu pelaksanaan pembelajaran yang akan dilakukan (Uno, 2012). Pembelajaran yang secara mendadak berubah menjadi pembelajaran daring tentunya banyak menghadapi berbagai kendala. Bahkan kesulitan dalam belajar tentu akan dialami oleh peserta didik. Kesulitan belajar ini berupa ketidakmampuan siswa dalam menguasai pengetahuan yang telah ditetapkan (Arifin, 2018). Karena banyak masalah yang terjadi di dalam proses pembelajaran daring melalui e-learning ini, maka pihak sekolah menerapkan pembelajaran blended learning agar tujuan pembelajaran dapat dicapai dengan baik. 
Tujuan pembelajaran merupakan suatu komponen yang paling utama dalam proses belajar mengajar. Menurut Pupuh Fathurrahman dan M. Sobry Sutikno (2011) bahwa kegiatan belajar mengajar mempunyai beberapa komponen yang berupa tujuan, bahan pembelajaran, kegiatan pembelajaran, metode pembelajaran, alat dan sumber pembelajaran serta alat evaluasi. Tujuan pembelajaran biasanya menggambarkan pengetahuan, sikap dan keterampilan yang ingin dicapai dalam setiap proses pembelajaran. Tujuan pembelajaran secara formal dirumuskan di dalam Rencana Pelaksanaan Pembelajaran (RPP). Perencanaan RPP dilakukan berguna untuk menyusun materi yang akan dipelajari, media yang akan digunakan, dan metode yang akan dipakai dalam pembelajaran, serta bagaimana bentuk penilaian pada suatu alokasi waktu untuk mencapai tujuan yang telah ditentukan (Majid, 2011). Hal ini dapat dilihat pada komponen tujuan pembelajaran. Perumusannya mengikuti rambu-rambu yang resmi melalui aturan hukum oleh pemerintah, seperti harus memenuhi unsur $A B C D$. Penjelasan unsur $A B C D$ dalam tujuan pembelajaran adalah $\mathrm{A}=$ Audience (petatar, siswa sasaran didik lainnya), $\mathrm{B}=$ Behaviour (perilaku yang dapat diamati sebagai hasil belajar), $\mathrm{C}=$ Condition (persyaratan yang dipenuhi agar perilaku yang diharapkan dapat tercapai) dan $\mathrm{D}=$ Degree (tingkat penampilan yang dapat diterima sebagai ukuran hasil belajar siswa).

Perumusan selanjutnya menggunakan KKO (Kata Kerja Operasional) dan mengandung pembelajaran yang menuntut HOTS (Higher Order Thinking Skills), karena berpikir tingkat tinggi dapat mendorong peserta didik untuk berpikir secara luas dan mendalam tentang materi pelajaran. Higher Order Thinking Skills (HOTS) atau keterampilan berpikir tingkat tinggi merupakan bagian dari taksonomi Bloom hasil revisi yang berupa kata kerja operasional yang terdiri dari analyze (C4), evaluate (C5) dan create (C6) yang dapat digunakan dalam penyusunan soal. Guru harus memiliki pengetahuan dan keahlian untuk menunjang pekerjaanya, sehingga dapat mengembangkan keterampilan berpikir tingkat tinggi peserta didik (Aydin \& Yilmaz, 2010). Hasil observasi awal menunjukkan bahwa tujuan pembelajaran sosiologi di SMA Negeri 3 Kota Pariaman secara umum belum tercapai secara maksimal, hal itu dapat dilihat dari siswa yang tidak bisa mengoperasikan e-learning dalam pelaksanaan pembelajaran. Sehingga hal tersebut berdampak pada pencapaian hasil belajar siswa yang belum mencapai batas ketercapaian Kriteria Ketuntasan Minimal (KKM) mata pelajaran sosiologi. Belajar tuntas merupakan suatu sistem pembelajaran yang sebagian besar siswanya diharapkan mampu menguasai basic learning objectiv dari suatu satuan unit pelajaran dengan tuntas (Sadirman, 2011).

\section{Metode Penelitian}

Metode yang digunakan dalam penelitian ini adalah metode kualitatif. Penelitian ini dilakukan dengan tujuan untuk mengetahui lebih dalam penerapan blended learning dalam mencapai tujuan pembelajaran sosiologi di masa pandemi Covid-19. Maka dengan metode kualitatif ini peneliti dapat menemukan berbagai jawaban atas pertanyaan melalui berbagai penuturan dan informasi langsung dari informan yang telah ditentukan sebelumnya. Tipe penelitian ini menggunakan studi kasus intrinsik karena peneliti ingin mendapatkan gambaran secara menyeluruh mengenai penerapan blended learning dalam mencapai tujuan pembelajaran sosiologi di SMA Negeri 3 Kota Pariaman. Subjek yang digunakan dalam penelitian ini adalah kepala sekolah, guru mata pelajaran sosiologi, serta siswa kelas X IPS dan XI IPS di SMA Negeri 3 Kota Pariaman. Penelitian ini dianalisis menggunakan teori tindakan sosial dari Max Weber. Pemilihan informan menggunakan teknik purposive sampling yaitu teknik yang pengambilan datanya tidak didasarkan strata, kedudukan, pedoman atau wilayah, tetapi didasarkan pada tujuan dan pertimbangan yang berhubungan dengan permasalahan penelitian (Sugiyono, 2017). Jumlah informan dalam penelitian ini ialah 15 orang yang terdiri dari kepala sekolah, 2 orang guru mata pelajaran sosiologi, dan 12 orang siswa dari kelas X dan kelas XI IPS di SMA Negeri 3 Kota Pariaman. Teknik pengumpulan data yang digunakan dengan cara observasi, wawancara dan

Jurnal Sikola: Jurnal Kajian Pendidikan dan Pembelajaran Vol. 3, No. 2, Th. 2021 
studi dokumentasi yang mengumpulkan data dengan mengamati langsung serta menemui informan ke lapangan (Sugiyono, 2017). Triangulasi data dilakukan dengan dua cara yaitu triangulasi sumber dan triangulasi teknik. Olahan data dianalisis dengan model interaktif Miles dan Huberman yaitu terdiri dari reduksi data, penyajian data dan penarikan kesimpulan (Basrowi dan Suwandi, 2008).

\section{Hasil Penelitian}

Pembelajaran saat ini memerlukan program pembelajaran yang sesuai dengan keadaan yang mana harus berbasis online atau daring. Bentuk upaya dari Kemendikbud dalam membantu terselenggaranya pendidikan bagi semua kalangan masyarakat di masa pandemi Covid-19 digantikan dengan pembelajaran yang memanfaatkan media elektronik atau yang sering disebut dengan e-learning, tidak terkecuali proses pembelajaran di SMA Negeri 3 Kota Pariaman juga memanfaatkan platform e-learning sebagai penunjang pembelajaran daring serta penerapan blended learning saat ini. Guru dituntut untuk berinovasi dalam pembelajaran daring ini khususnya menggunakan e-learning, disini juga dapat dilihat apakah kemajuan teknologi dapat menggantikan peranan guru dalam mengajar (Ferdiana, 2020). Namun proses pembelajaran menggunakan $e$ learning banyak ditemukan hambatan dalam pelaksanaannya, maka dari itu pihak sekolah menerapkan pembelajaran berbasis blended learning agar tujuan pembelajaran dapat tercapai khususnya pada mata pelajaran sosiologi di SMA Negeri 3 Kota Pariaman.

Berdasarkan hasil penelitian yang telah dilakukan terdapat beberapa upaya yang dilakukan guru dalam mencapai tujuan pembelajaran pada penerapan blended learning dalam mata pelajaran sosiologi di SMA Negeri 3 Kota Pariaman sebagai berikut:

\section{Penerapan E-learning}

Pembelajaran daring sosiologi di SMA Negeri 3 Kota Pariaman tentunya memerlukan strategi pembelajaran yang tepat demi tercapainya tujuan pembelajaran yang sesuai dengan indikator pembelajaran, terutama pembelajaran yang dengan memanfaatkan platform e-learning. Hal ini diungkapkan dari hasil wawancara dengan Ibu YD, sebagai berikut:

“... Pada awal pandemi covid-19 ibuk melaksanakan pembelajaran dengan full daring yang memanfaatkan berbagai aplikasi seperti whatsapp, google classroom dan e-learning sekolah, akan tetapi pada kenyataannya masih banyak siswa yang tidak mengikuti pembelajaran sosiologi ini dengan baik".

Hal serupa juga diungkapkan oleh bapak AZ, sebagai berikut:

“... Di bulan Maret 2020 ketika awal sekolah daring dimulai, bapak menggunakan whatsapp untuk mengambil absen dan mengirim materi pada siswa. Namun, pada Bulan April beralih menggunakan google classroom agar mempermudah penataan kelas secara daring. Lalu pada Bulan September kami memakai e-learning yang telah disediakan sekolah untuk meminimalisir kendala yang dihadapi, segala bentuk materi pembelajaran dan segala bentuk test didistribusikan melalui e-learning, serta komunikasi juga dilakukan secara online, namun pada kenyataannya masih banyak siswa yang tidak mengikuti pembelajaran dengan baik".

Dari wawancara diatas, dapat disimpulkan bahwa selama pandemi Covid-19 pihak sekolah menggunakan berbagai jenis Learning Management System (LMS) dalam mendukung pembelajaran. Namun masih terdapat berbagai macam kendala.

Hal ini diperkuat dengan hasil wawancara yang dilakukan dengan kepala sekolah SMA Negeri 3 Kota Pariaman, yaitu Bapak AM yang menyatakan bahwa: 
“... Pada awal masa pandemi Covid-19 di bulan Maret 2020 kemarin seluruh sekolah di Kota Pariaman memutuskan untuk melakukan pembelajaran secara daring dengan memanfaatkan berbagai platform yang tepat agar pembelajaran tetap berjalan dengan baik. Mulai dari memanfaatkan whatsapp, google classroom, hingga e-learning yang sampai saat ini masih digunakan. Tapi yang namanya pembelajaran secara daring, tentu menemukan banyak kendala bagi siswa dan guru sehingga banyak siswa yang tidak mengerti dengan materi yang disampaikan oleh guru mereka masing-masing yang menyebabkan hasil belajar siswa tersebut menurun. Maka dengan ditemukannya permasalahan ini, saya selaku Kepala Sekolah memberlakukan pembelajaran dengan menerapkan sistem blended learning, yang mana para siswa secara bergantian atau yang biasanya disebut dengan sistem shift untuk melakukan pembelajaran secara tatap muka dan daring setiap minggunya, dan bagi siswa yang shift online tetap belajar dari rumah dengan memanfaatkan platform e-learning yang telah disediakan oleh pihak sekolah".

Berdasarkan hasil wawancara di atas, maka dapat disimpulkan bahwa guru serta pihak sekolah dalam mengatasi kendala atau permasalahan selama pembelajaran daring di masa pandemi Covid-19 adalah dengan cara menerapkan pembelajaran berbasis blended learning. Platform e-learning tetap dimanfaatkan untuk siswa yang belajar secara daring, namun pada saat pembelajaran luring guru mencoba sedikit menjelaskan kembali materi yang sudah diberikan melalui e-learning tersebut agar siswa dapat lebih memahami pembelajaran dengan baik.

Hal tersebut juga sesuai dengan apa yang telah disampaikan siswa yang bernama NJ bahwa:

“... Pada awal kemunculan covid-19 sekolah menerapkan pembelajaran secara full daring dengan hanya memanfaatkan whatsapp saja, lalu setelah itu diterapkan pembelajaran dengan menggunakan google classroom, dan setelah masuk tahun ajaran baru berubah lagi peraturan dari sekolah serta guru untuk memakai e-learning dalam proses pembelajaran".

Berdasarkan hasil wawancara diatas, dapat disimpulkan bahwa majelis guru dan kepala sekolah dalam mengatasi berbagai kendala yang dihadapi selama pembelajaran daring ialah dengan menggunakan berbagai macam jenis Learning Management System (LMS) mulai dari whatsapp, google classroom hingga e-learning. Akan tetapi masih banyak ditemukan berbagai kendala atau permasalahan, sehingga pihak sekolah menerapkan pembelajaran berbasis blended learning.

\section{Penerapan Blended Learning}

Pembelajaran daring merupakan pembelajaran yang memanfaatkan jaringan internet dan Learning Management System (LMS) dengan aksesibilitas, konektivitas, fleksibilitas dan kemampuan untuk memunculkan berbagai jenis interaksi pembelajaran. Pembelajaran daring ini tidak terlepas dari berbagai permasalahan terutama saat menggunakan e-learning, seperti jaringan internet yang tidak stabil, website e-learning yang sering error sehingga sulit untuk diakses, serta akun siswa yang sering mengalami masalah atau sulit untuk login ke akun e-learning mereka. Sehingga SMA Negeri 3 Kota Pariaman menerapkan pembelajaran berbasis blended learning sesuai dengan yang telah dibahas sebelumnya.

Hal ini sesuai dengan wawancara yang telah dilakukan pada salah satu siswa yaitu AS sebagai berikut:

“... Saya sulit memakai e-learning karena jaringan di rumah saya tidak stabil dan tidak lancar serta websitenya yang sering error sehingga tidak bisa dibuka. Saya juga tinggal di kabupaten, karena itulah banyak mengalami masalah. Disini jaringan yang cukup

Jurnal Sikola: Jurnal Kajian Pendidikan dan Pembelajaran Vol. 3, No. 2, Th. 2021 
memadai hanya paket telkomsel, sedangkan untuk paket internet saya hanya memakai tri".

Hal senada juga dikatakan oleh NR sebagai berikut:

“... Saya kesulitan dalam mengakses e-learning karena jaringan saya sering hilang, terkadang hal tersebut membuat saya malas untuk mengakses e-learning tersebut. Sehingga saya sering ketinggalan mengambil absen dan mengirim tugas. Sebenarnya e-learning ini cukup bagus untuk menunjang pembelajaran, akan tetapi websitenya sering error dan logout dengan sendirinya dari akun saya".

Dari hasil wawancara diatas dapat disimpulkan bahwa siswa sering mengalami kendala dalam mengakses e-learning, yang disebabkan oleh jaringan yang tidak stabil karena tempat tinggal siswa lebih dominan berada di luar Kota Pariaman. Lalu siswa juga kesulitan karena seringnya website e-learning error, serta akun e-learning yang sering keluar masuk (logout) dengan sendirinya. Sehingga membuat siswa tersebut menjadi malas membuka e-learning saat belajar. Oleh karena itu sekolah menerapkan pembelajaran berbasis blended learning.

Hal ini sesuai dengan pernyataan yang dikatakan oleh Ibu YD, sebagai berikut:

“... Permasalahan di e-learning yang menyangkut website error biasanya ibuk mengatasi hal tersebut dengan mencari alternatif proses belajar mengajar menggunakan bantuan whatssapp grup atau google classroom untuk sementara waktu agar tujuan pembelajaran tetap tercapai dengan baik. Selanjutnya sesuai edaran yang berlaku di sekolah kami menerapkan pembelajaran blended learning dengan sistem shift setiap minggunya".

Hal serupa juga dikatakan oleh Bapak AZ, yang menyatakan bahwa:

“... Para siswa banyak mengalami kendala jaringan internet yang membuat proses pembelajaran berjalan dengan lambat, hal ini dikarenakan siswa tersebut banyak yang tinggal di luar Kota Pariaman. Sehingga pihak sekolah menerapkan pembelajaran blended learning atau juga bisa disebut gabungan belajar tatap muka dengan belajar daring".

Hal ini diperkuat langsung oleh pernyataan dari Kepala Sekolah SMA Negeri 3 Kota Pariaman yaitu Bapak AM sebagai berikut:

“... Di SMA Negeri 3 Kota Pariaman ini sebagian besar banyak siswa yang mengeluh terkait koneksi jaringan internet yang sering tidak stabil, serta tidak seluruh siswa juga yang memiliki handphone (HP) android. Berangkat dari hal tersebut, sekolah memberikan berbagai fasilitas seperti memanfaatkan komputer di laboratorium, melengkapi setiap kelas dengan wi-fi agar jaringan internet lebih stabil. Akan tetapi ada kalanya website e-learning tetap error sehingga kami lebih memilih menerapkan pembelajaran berbasis blended learning atau campuran pembelajaran tatap muka dan daring sesuai dengan surat edaran yang berlaku di Kota Pariaman".

Berdasarkan hasil wawancara guru sosiologi dan Kepala Sekolah SMA Negeri 3 Kota Pariaman dapat ditarik kesimpulan bahwa agar tujuan pembelajaran tetap tercapai maka majelis guru dan pihak sekolah menerapkan pembelajaran gabungan antara tatap muka dan daring (blended learning) dengan sistem shift, yaitu membagi siswa menjadi 2 rombel dalam satu kelas. Misalnya 10 orang belajar dari rumah, dan 10 orang lagi belajar di sekolah. Selain itu sekolah juga menyediakan fasilitas laboratorium dan wi-fi di setiap kelas. 


\section{Penggunaan Bahan Ajar}

Pembelajaran daring pada masa pandemi haruslah menggunakan media teknologi sebagai akses yang tepat dalam menyampaikan materi pada siswa, agar pembelajaran yang diajarkan oleh guru dapat dengan mudah dipahami oleh siswa tersebut. Pada pembelajaran daring sangat dibutuhkan media online seperti whatsapp, google classroom dan e-learning untuk mendukung proses pembelajaran baik bagi guru maupun siswa. Hal ini diungkapkan dari hasil wawancara dengan Ibu YD, sebagai berikut:

“... Selama pembelajaran daring ibuk sering menggunakan berbagai aplikasiaplikasi yang menunjang pembelajaran seperti aplikasi editor video, aplikasi powerpoint, aplikasi microsoft word, dan lain sebagainya. Ibuk memanfaatkan aplikasi tersebut untuk membuat media pembelajaran agar terlihat lebih menarik dan mudah dipahami oleh siswa. Biasanya ibuk menggunakan video pembelajaran yang ibuk rekam dan edit sendiri, karena siswa umumnya lebih mudah memahami pembelajaran yang dijelaskan langsung oleh guru yang bersangkutan daripada video pembelajaran yang diambil dari berbagai sumber seperti youtube. Selain itu ibu juga membuat slide powerpoint yang lebih rinci serta bahan ajar berbentuk word atau pdf. Untuk media pembelajaran tersebut telah ibu terapkan pada berbagai platform yang digunakan selama pembelajaran daring, namun pada platform e-learning ini lebih memiliki fitur yang lebih lengkap dan terorganisir dibandingkan dengan platform yang lain. Melalui e-learning ini absensi guru dan siswa juga bisa direkap secara langsung, sehingga kepala sekolah juga bisa melihat perkembangan pembelajaran melalui e-learning tersebut".

Hal serupa juga diungkapkan oleh bapak AZ, sebagai berikut:

“... Bapak ketika belajar daring ini lebih sering menggunakan media powerpoint atau mengirim bahan ajar berbentuk pdf kepada siswa, sedangkan untuk video pembelajaran biasanya bapak ambil dari youtube karena bapak kurang ahli dalam bidang membuat dan mengedit video sendiri sehingganya video dari youtube menjadi alternatif dari bapak agar pembelajaran yang diberikan kepada siswa terkesan lebih menarik dan tidak monoton. Ketika siswa tidak paham dengan materi yang telah disajikan maka alternatif lain yang dapat bapak lakukan adalah dengan cara melakukan video conference dengan menggunakan zoom meeting sesuai jadwal yang telah ditentukan".

Dari wawancara diatas terlihat bahwa dalam proses belajar mengajar daring para majelis guru di SMA Negeri 3 Kota Pariaman menggunakan berbagai macam media sebagai pendukung pembelajaran daring yang berupa video pembelajaran yang dibuat langsung oleh guru itu sendiri ataupun video yang diambil dari youtube, membuat slide powerpoint yang lebih rinci dan ringkasan materi berbentuk word atau pdf serta melakukan video conference melalui zoom meeting untuk mendukung proses pembelajaran, terutama pada pembelajaran sosiologi.

Hal ini dikonfimasi langsung oleh Kepala Sekolah SMA Negeri 3 Kota Pariaman yaitu Bapak AM, yang mengatakan bahwa:

“... Para guru dalam menunjang proses pembelajarannya menggunakan berbagai media pembelajaran yang sangat bervariasi dan berbeda-beda sesuai dengan kondisi kelas dan kebutuhan materi serta kebutuhan siswanya masing-masing. Media yang paling umum dan paling banyak digunakan adalah media berupa slide powerpoint serta ringkasan materi dalam bentuk word atau pdf karena dianggap lebih mudah dan efisien. Sebagian ada juga guru yang membuat sendiri video pembelajaran agar siswanya lebih mudah memahami materi-materi yang mereka ajarkan, seperti halnya guru sosiologi. Selain itu, beberapa guru juga menggunakan video conference

Jurnal Sikola: Jurnal Kajian Pendidikan dan Pembelajaran Vol. 3, No. 2, Th. 2021 
untuk menjelaskan materi pelajaran. Sejauh ini platform yang menyediakan fitur yang lengkap sebagai wadah penyedia media pembelajaran adalah platform elearning".

Berdasarkan penjelasan dari Kepala Sekolah diatas dapat disimpulkan bahwa terdapat berbagai macam media yang digunakan dalam mendukung pembelajaran saat ini yang disesuaikan dengan kondisi kelas dan kebutuhan materi serta kebutuhan siswa itu sendiri. Sehingga platform yang dinilai paling efektif dalam mendukung pembelajaran sosiologi di SMA Negeri 3 Kota Pariaman ialah dengan menggunakan platform e-learning, karena segala kegiatan yang dilakukan oleh siswa dan guru dapat dipantau secara langsung oleh kepala sekolah.

Hal ini juga sejalan dengan yang disampaikan oleh TYA bahwa:

“... Ketika belajar sosiologi, guru mengirim materi dalam bentuk pdf dan mengirim powerpoint di e-learning. Akan tetapi pada materi tertentu yang dirasa agak sulit, guru mencoba menjelaskan lewat video pembelajaran. Menurut saya pribadi lebih bagus menggunakan powerpoint karena materi disana lebih jelas point-point yang akan dibahas serta ditambah dengan gambar-gambar sebagai pendukung dari materi tersebut".

Dari hasil wawancara diatas dapat disimpulkan bahwa pada pembelajaran daring sosiologi di SMA Negeri 3 Kota Pariaman disaat pandemi ini menggunakan berbagai macam media pembelajaran demi tercapainya tujuan pembelajaran. Media yang digunakan dalam mendukung pembelajaran ini berupa buku teks, bahan ajar berbentuk word atau pdf, slide powerpoint, dan video pembelajaran yang dikirim melalui platform e-learning.

\section{Penggunaan Alat Pembelajaran}

Alat pembelajaran merupakan suatu benda yang digunakan oleh guru dan siswa untuk membantu agar proses pembelajaran dapat berjalan dengan baik, seperti smartphone, komputer, wi$f i$, dan lainnya. Proses penerapan e-learning dalam pembelajaran sosiologi di SMA Negeri 3 Kota Pariaman dilakukan dengan menggunakan HP (handphone/smartphone) yang dimiliki oleh masingmasing peserta didik. Hal ini banyak ditemukan kendala dalam proses pembelajaran daring, terutama pada mata pelajaran sosiologi menggunakan media e-learning. Hal ini sejalan dengan hasil wawancara yang telah dilakukan peneliti dengan guru sosiologi yaitu Ibu YD, sebagai berikut:

“... Selama ibuk ngajar daring ini banyak siswa yang mengeluh karena tidak memiliki HP sama sekali, atau ada yang memiliki HP namun tidak HP android, ada juga siswa yang HP nya bersama dengan saudara mereka, sehingga siswa yang tidak memiliki HP android tersebut diperintahkan untuk datang ke sekolah untuk belajar dengan menggunakan komputer yang ada di labor TIK saat ada ulangan atau ujian, dan untuk kegiatan pembelajaran para siswa yang tidak memiliki HP android tersebut akan ibuk beri ringkasan materi dan tugasnya secara langsung di sekolah sesuai dengan waktu yang telah ditentukan".

Hal serupa juga disampaikan oleh Bapak AZ, yang mengatakan bahwa:

“... Ada sebagian siswa yang tidak memiliki HP dalam mendukung proses pembelajaran dikarenakan faktor ekonomi siswa itu sendiri. Jadi siswa yang tidak memiliki HP tersebut biasanya mereka memakai HP milik saudaranya atau temannya, atau datang secara langsung ke sekolah untuk mengantar tugas-tugas yang diberikan oleh guru kepada siswa". 
Berdasarkan wawancara yang telah dilakukan dengan guru sosiologi di atas, maka dapat disimpulkan bahwa siswa yang memiliki keterbatasan alat dalam mendukung proses pembelajaran mereka melakukan upaya dengan meminjam HP milik saudara atau temannya, menggunakan komputer yang ada di labor TIK sekolah atau dengan cara menemui gurunya secara langsung untuk belajar dan menyerahkan tugas.

Hal senada juga disampaikan langsung oleh Kepala Sekolah SMA Negeri 3 Kota Pariaman yaitu Bapak AM, yang mengatakan bahwa:

“... Jika ditinjau dari selama pelaksanaan pembelajaran daring di masa pandemi ini, sebagian siswa baik dari kelas X, XI dan XII sebagian ada yang mengeluh karena tidak memiliki HP sama sekali, ada juga yang memiliki HP namun tidak HP yang berbasis android sehingga banyak siswa yang tidak berpartisipasi dalam proses pembelajaran. Oleh karena itu kami melakukan tindakan dengan menginstruksikan kepada siswa tersebut untuk datang ke sekolah dan menggunakan komputer labor, serta kami juga telah melengkapi masing-masing kelas dengan pemasangan wi-fi bagi siswa yang tidak memiliki kuota internet dan akses jaringan yang lemah di lingkungan tempat tinggalnya".

Berdasarkan pernyataan dari Kepala Sekolah SMA Negeri 3 Kota Pariaman dapat disimpulkan bahwa guru dan sekolah dalam rangka mencapai tujuan pembelajaran secara daring dalam pengadaan alat ialah dengan menyediakan komputer labor TIK bagi siswa yang tidak memiliki HP serta telah disediakan wi-fi di setiap kelas agar siswa yang terkendala jaringan dan kuota internet dapat belajar menggunakan HP masing-masing di sekolah karena keterbatasan komputer di labor yang tidak dapat menampung seluruh siswa.

Hal ini sejalan dengan hasil wawancara yang telah dilakukan peneliti pada siswa yang bernama RNS sebagai berikut:

“... Saya sebenarnya sedikit kesulitan dalam belajar online ini. Karena HP yang saya gunakan tersebut adalah milik bersama dengan abang dan adik saya. Jadi saya sering terlambat dalam pengambilan absen dan mengirim tugas, karena itu juga nilai saya jadi turun. Akan tetapi ibuk juga sering menyuruh untuk mengumpulkan tugas ke sekolah secara langsung".

Selanjutnya hal yang sama juga disampaikan oleh CD sebagai berikut:

"... Saya tidak bisa belajar online karena tidak memiliki HP android untuk membuka e-learning saat proses belajar berlangsung. Kadang saya meminjam HP tetangga untuk membuka e-learning, akan tetapi kalau misalnya tetangga saya juga sedang memakai HP tersebut maka saya otomatis harus pergi ke sekolah untuk mengambil absen dan sekalian mengantar tugas kepada bapak".

Berdasarkan hasil wawancara diatas, dapat disimpulkan bahwa para siswa mengalami berbagai kendala dalam ketersediaan alat saat pembelajaran online di SMA Negeri 3 Kota Pariaman yaitu berupa siswa yang tidak memiliki HP android, kepemilikan HP siswa yang satu bersama dengan saudaranya, serta keterbatasan komputer di laboratorium sekolah, sehingga guru memberikan solusi kepada siswa yang bermasalah tersebut untuk datang langsung ke sekolah saat jam pelajaran, sehingga siswa tersebut tetap bisa melaksanakan proses pembelajaran sosiologi dengan baik.

\section{Upaya Menyangkut Sumber Belajar}

Sumber belajar merupakan segala yang berguna bagi guru dan siswa berupa informasi yang digunakan dalam membantu proses belajar mengajar secara efektif dan efesien. Penggunaan sumber belajar sangat penting dalam mendukung pembelajaran daring yang berupa buku cetak maupun buku berbasis elektronik dengan bantuan internet. Di SMA Negeri 3 Kota Pariaman saat

Jurnal Sikola: Jurnal Kajian Pendidikan dan Pembelajaran Vol. 3, No. 2, Th. 2021 
ini menggunakan sumber belajar berupa bahan ajar berbentuk file yang dikirim oleh guru melalui e-learning dalam rangka menunjang proses belajar mengajar. Hal ini diungkapkan oleh Ibu YD, sebagai berikut:

“... Karena saat ini kami masih melakukan proses pembelajaran secara daring, tentunya sumber belajar yang dipakai juga disesuaikan dengan media berbasis elektronik yang memanfaatkan akses internet. Biasanya ibuk ketika mengajar menggunakan e-book dan mengirim file bahan ajar berbentuk pdf kepada siswa di setiap pertemuan, sumber belajar ini juga diambil dari youtube. Ibuk juga melakukan pembelajaran berbasis lingkungan sekitar siswa agar mereka bisa mengamati secara langsung peristiwa-peristiwa yang bisa dijadikan sebagai sumber belajar".

Hal serupa juga diungkapkan oleh Bapak AZ, sebagai berikut:

“... Bapak kalau ngajar biasanya upload sumber belajar pakai pdf saja, tiap pertemuan bapak ngirim materi per-indikator sekalian dengan LKPD. Materi yang bapak kirim dalam bentuk file tersebut merupakan gabungan dari beberapa sumber seperti buku cetak erlangga, buku cetak yudisthira, e-book dan jurnal. Lalu bapak buat bahan ajarnya sesuai dengan indikator dalam bentuk pdf tadi dan bapak kirim ke e-learning".

Dari hasil wawancara diatas dapat disimpulkan bahwa penggunaan sumber belajar pada mata pelajaran sosiologi di SMA Negeri 3 Kota Pariaman selama pembelajaran daring menggunakan bahan ajar berupa buku elektronik yang dibuat dalam bentuk file pdf, video pembelajaran yang diambil melalui youtube serta sumber belajar yang berbasis lingkungan tempat tinggal siswa.

\section{Pembahasan}

Berdasarkan analisis teori tindakan sosial Max Weber, menurut Weber ada beberapa tipe tindakan sosial, dan hasil penelitian ini sesuai dengan tindakan rasionalitas instrumental (berorientasi tujuan) karena upaya yang menyangkut pemilihan seperti penerapan e-learning, blended learning, media pembelajaran dan lain sebagainya tersebut didasarkan atas pertimbangan dan pilihan yang berkaitan dengan tercapainya tujuan pembelajaran sosiologi, serta memanfaatkan ketersediaan alat yang digunakan untuk mencapai tujuan pembelajaran tersebut.

Terdapat beberapa model pembelajaran yang bisa digunakan oleh guru sebagai media penyampaian materi pembelajaran, yaitu dengan cara pembelajaran campuran dimana merupakan kombinasi antara metode pembelajaran yaitu metode tatap muka dan daring (Magdalena et al., 2020). Pembelajaran tatap muka dan daring ini merupakan kegiatan pembelajaran interaktif yang mana dapat berdiri sendiri atau dipadukan (blended learning) dalam pembelajaran di sekolah agar tujuan pembelajaran dapat tercapai secara maksimal oleh siswa. Pembelajaran daring ini dapat memanfaatkan berbagai macam platform yang ada agar pembelajaran terkesan kreatif, efektif, dan efesien, beberapa diantaranya guru memanfaatkan platform whatsapp, google classroom, edmodo, serta e-learning (Nikmah, 2020). Sebagai suatu strategi pembelajaran, e-learning merupakan pilihan yang ideal saat pembelajaran daring ini. Pada dasarnya pemanfaatan e-learning terkait dengan alat elektronik seperti komputer dan smartphone yang tersambung dengan jaringan interet untuk menunjang pembelajaran siswa kapanpun dan dimanapun tanpa harus datang langsung ke kampus atau ke sekolah (Yuliana \& Bahri, 2020). Pembelajaran menggunakan e-learning ini dapat dijadikan wadah bagi guru untuk mengambil absensi siswa, memberikan materi, memberi tugas dan kuis, dan melakukan penilaian kepada siswa secara faktual dan efesien sehingga proses belajar mengajar tetap berlangsung kondusif.

Jurnal Sikola: Jurnal Kajian Pendidikan dan Pembelajaran Vol. 3, No. 2, Th. 2021 
Dalam hal media pembelajaran, guru melakukan inovasi dalam proses pembelajaran dengan memanfaatkan beberapa aplikasi yang ada (Nikmah, 2020). Para guru berusaha membuat video pembelajaran terkait dengan materi atau pokok bahasan yang akan diajarkan kepada siswa agar siswa paham dengan penjelasan guru melalui video. Selain itu, guru membuat slide powerpoint yang rinci tentang pokok bahasan materi yang dipelajari, serta membagikan bahan ajar berbentuk word atau pdf agar membantu siswa dalam proses belajar mengajar pada mata pelajaran sosiologi. Media pembelajaran yang digunakan guru tentunya akan berbeda-beda yang disesuaikan dengan kondisi kelas, kebutuhan materi, serta kebutuhan siswa pada setiap kelas. Hal lain yang dapat dimanfaatkan guru sebagai wadah untuk menjelaskan materi kepada siswa ialah dengan memanfaatkan fitur video converence menggunakan aplikasi zoom meeting. Ada berbagai macam alat yang dimanfaatkan oleh guru sebagai pendukung jalannya proses belajar mengajar, pada pembelajaran daring alat belajar yang sangat penting demi jalannya proses belajar mengajar ialah alat elektronik yang dapat terhubung dengan jaringan internet. Alat utama yang dapat dimanfaatkan berupa komputer/PC, laptop, dan smartphone serta gawai (Setiono et al., 2020). Namun, pada kenyataannya tidak semua siswa memiliki alat elektronik yang dapat menunjang proses pembelajaran daring, hal ini menuntut sekolah menyediakan fasilitas pendukung pembelajaran seperti penyediaan komputer sekolah bagi siswa yang tidak memiliki smartphone serta wifi bagi siswa yang keterbatasan kuota internet.

Buku merupakan salah satu sumber belajar yang utama yang digunakan guru dan siswa pada proses pembelajaran. Mengingat kondisi pembelajaran yang dilakukan secara daring saat ini sumber belajar dikemas secara elektronik dan dapat diakses oleh siswa dengan memanfaatkan jaringan internet, sehingga para siswa dapat melakukan interaksi dengan sumber belajar tersebut kapanpun dan dimanapun. Hal ini juga berarti bahwa pada saat proses pembelajaran menggunakan e-learning dapat menjadikan buku dalam bentuk soft file dalam format word atau pdf yang dapat dibagikan kepada setiap siswa sebagai adaptasi metode pembelajaran ini. Syahruddin dalam (Abbas, dkk, 2020) menyatakan bahwa memanfaatkan lingkungan sosial-budaya sebagai sumber belajar diyakini dapat membuat pembelajaran lebih bermakna dan bervariasi sehingga tidak membosankan bagi siswa. Nilai, budaya, kebiasaan, tradisi dan adat istiadat, serta moral tertentu dalam masyarakat di lingkungan sekitar siswa perlu dipelajari oleh siswa tersebut (Subiyakto \& Mutiani, 2019). Mengingat sumber belajar yang bisa dimanfaatkan dari mana saja seperti, buku, internet, dan lingkungan selama itu berkaitan dengan materi yang akan diajarkan meskipun pembelajaran dilaksanakan melalui e-learning (Yuniarti et al., 2020). Hal lain yang dilakukan guru ialah dengan memperpanjang jangka waktu penyelesaian tugas dan sedikit lebih fleksibel. Ini dilakukan karena ada siswa yang yang memiliki keterbatasan dalam hal koneksi atau jaringan internet. Terlebih bagi siswa yang tempat tinggalnya sama sekali tidak memiliki jaringan internet. Para guru dapat menyederhanakan materi dan tugas yang diberikan kepada siswa agar lebih mudah dan cepat dipahami oleh siswa tersebut (Nikmah, 2020).

\section{Kesimpulan}

Berdasarkan penelitian yang telah dilakukan oleh peneliti, bahwa dalam mencapai tujuan pembelajaran sosiologi di SMA Negeri 3 Pariaman diterapkannya penggunaan model pembelajaran secara blended learning (campuran pembelajaran tatap muka dan daring) karena masih terdapat banyak permasalahan dalam pembelajaran daring menggunakan whatsapp, google classroom bahkan e-learning. Pembelajaran daring juga didukung dengan penggunaan berbagai media pembelajaran seperti video, slide powerpoint, dan bahan ajar berbentuk word/pdf. Penggunaan alat berupa pemanfaatan berbagai media elektronik untuk kebutuhan belajar. Sumber belajar yang berupa pemanfaatan buku elektronik, internet, serta lingkungan siswa sebagai sumber belajar utama bagi siswa serta perpanjangan waktu pengumpulan tugas bagi siswa yang terkendala jaringan.

Jurnal Sikola: Jurnal Kajian Pendidikan dan Pembelajaran Vol. 3, No. 2, Th. 2021 
Benny Muhammad, Junaidi Junaidi

\section{Daftar Pustaka}

Arifin, Z. (2018). Meningkatkan Hasil Belajar dengan Strategi Pembelajaran Peningkatan Kemampuan Berpikir. 2(2), 42-49.

Ferdiana, S. (2020). Persepsi Mahasiswa tentang Penggunaan Media Daring pada Program Studi S1 Ilmu Gizi Sekolah Tinggi Ilmu Kesehatan Surabaya selama Masa Pandemi Corona Virus Disease (COVID-19). Indonesian Journal of Science Learning, 2(2), 8-25.

Magdalena, I., AzharI, N., \& Hesti, S. (2020). Strategi pembelajaran daring aktif, kreatif, menyenangkan di sd negeri 1 pegagan lor. 2, 306-317.

Nasution, S. H. (2018). Pentingnya Literasi Teknologi Bagi Mahasiswa Calon Guru Matematika. Jurnal Kajian Pembelajaran Matematika, 2(1), 14-18.

Nikmah, N. (2020). Strategi Pembelajaran Daring Pada Masa Pandemi Covid-19 (Studi di Jurusan Akuntansi Politeknik Negeri Banjarmasin) Online Learning Strategies During The Pandemic Covid19 ( A Study at Accounting Department, Banjarmasin State Polytechnic ), 2(2).

Pratama, R. E., \& Mulyati, S. (2020). Pembelajaran Daring dan Luring pada Masa Pandemi Covid-19. 1(2), 49-59. https://doi.org/10.30870/gpi.v1i2.9405

Setiono, P., Handayani, E., Selvia, \& A., W. W. (2020). Strategi Guru Dalam Pembelajaran Daring Pada Masa Covid-19 Di Sekolah Dasar. 3(3), 402-407.

Subiyakto, B., \& Mutiani, M. (2019). Internalisasi Nilai Pendidikan Melalui Aktivitas Masyarakat Sebagai Sumber Belajar Ilmu Pengetahuan Sosial. Khazanah: Jurnal Studi Islam Dan Humaniora, 17(1), 137. https://doi.org/10.18592/khazanah.v17i1.2885

Yuliana, E., \& Bahri, S. (2020). Strategi Belajar Dengan Memanfaatkan E-Learning Pada Masa Pandemi Di Sdn 2 Kembang Kerang Aikmel. BADA'A : Jurnal Ilmiah Pendidikan Dasar, 2(2), 219-228. https://doi.org/10.37216/badaa.v2i2.361

Yuniarti, D., Subiyakto, B., \& Putra, M. A. H. (2020). Economic Activities in Kuin Floating Market as a Learning Resource on Social Studies. The Kalimantan Social Studies Journal, 1(2), 130. https://doi.org/10.20527/kss.v1i2.2028 